\title{
Evaluation of the Seroprevalence of Hepatit $A$ and Vaccination Status in Children Aged Two and Sixteen Years
}

\author{
Iki-On Altı Yaș Arası Çocukların Hepatit A Seroprevalansı ve Așılanma Durumunun \\ Değerlendirilmesi
}

\author{
Nurcan KOLANCALI1, Zehra Esra ÖNAL1, Sebahat AKSARAY2, Çağatay NUHOĞLU1 \\ 1 University of Health Sciences, Haydarpaşa Numune Training and Research Hospital, Clinic of Pediatrics, Istanbul, Turkey \\ 2 University of Health Sciences, Haydarpaşa Numune Training and Research Hospital, Clinic of Medical Microbiology, Istanbul, Turkey
}

\begin{abstract}
Objective: In this study; the aim was to evaluate the seroprevalence of hepatitis A virus (HAV) in 2-16 year age group, and the rate of hepatitis A vaccination

Materials and Methods: This study was conducted on 400 children aged between 2 and 16 years with no chronic diseases who attended the pediatrics outpatient clinic in Health Sciences University, Haydarpaşa Numune Training and Research Hospital. After obtaining informed consent from the parents, blood samples were taken for investigating serological markers for hepatitis $A$ in the microbiology laboratory using the ELISA method. The parents were asked whether or not their children had been vaccinated against hepatitis $A$.

Results: In this study $44.3 \%$ of the participants included were girls and $55.8 \%$ were boys. The mean age of the children was $10.8 \pm 4.18$ years. $27.3 \%$ of patients were anti-HAV IgG-positive, and $11 \%$ had been vaccinated against hepatitis $A$. When we compared preschool and school age patients, anti-HAV IgG positivity was detected in all children who were vaccinated in the preschool group; while 5.9\% of unvaccinated children were anti-HAV IgG-positive and $94.1 \%$ were negative. It was found that school age children were unvaccinated, and anti-HAV IgG was positive in $19.6 \%$ of the children and negative in $80.4 \%$ of the children.

Conclusion: In our study, although the prevalence of hepatitis A was found to be low compared to the eastern and southeastern cities of our country, it is still higher than in the developed countries. In order to prevent hepatitis A infection, it is necessary to improve the socio-economic conditions of the country, to create better sanitary conditions and hygienic practices, and raise awareness of the infection.

Keywords: Hepatitis A virus, vaccination, seroprevalence
\end{abstract}

\section{OZZ}

Amaç: Bu çalışmada 2-16 yaş grubu olgularda, hepatit A virüsünün (HAV) seroprevalansının ve hepatit A aşısının yaptıııma oranlarının değerlendirilmesi amaçlandı.

Gereç ve Yöntemler: Sağlık Bilimleri Üniversitesi, Haydarpaşa Numune Eğitim ve Araştırma Hastanesi, Çocuk Polikliniği'ne başvuran 2-16 yaş arası, kronik hastalığı olmayan 400 çocuk araştırma kapsamına alındı. Ailelerin onayı alındıktan sonra alınan kan örneği tıbbi mikrobiyoloji laboratuvarına gönderilip ELISA yöntemi ile hepatit A serolojik belirteçleri çalışıldı. Hastalara, hepatit A aşısını yaptıııp yaptırmadıkları soruldu.

Bulgular: Çalışmaya alınan çocukların 177'si $(\% 44,3)$ kız, 223'ü $(\% 55,8)$ erkek olup ortalama yaşları 10,8+/-4,18 yıldı. Olguların 109'unun $(\% 27,3)$ anti-HAV IgG'si pozitifti ve $44^{\prime}$ 'ü $(\% 11)$ hepatit $A$ aşısı yaptırmıştı. Okul öncesi ve okul dönemi olarak karşılaştırdığımızda okul öncesi grupta aşı olan tüm çocuklarda antiHAV IgG pozitifliği görülürken; aşı olmayan çocukların \%5,9'unda anti-HAV lgG pozitif, \%94,1'inde negatiftir. Okul dönemindeki çocuklarda aşı varlığı görülmezken, çocukların \% 19,6'sında anti-HAV lgG pozitif iken, \%80,4'ünde negatiftir.

Sonuç: Çalışmamızda, hepatit A prevalansı ülkemizin Doğu ve Güneydoğu illerine göre düşük bulunsa da halen gelişmiş ülkelerin seroprevalansına göre yüksek seyretmektedir. Bunu önlemek için ülkenin sosyo-ekonomik şartlarının düzeltilmesi ve toplumun bilinçlendirilmesi gerekmektedir. Sağlık Bakanlığı Ulusal Aşı Programı kapsamındaki hepatit A aşısı ile HAV enfeksiyonu sıklı̆ı̆ı azalacaktır. Anahtar Kelimeler: Hepatit A virüsü, aşılama, seroprevalans

Kolancalı N, Önal ZS, Aksaray S, Nuhoğlu Ç. Evaluation of the Seroprevalence of Hepatit A and Vaccination Status in Children Aged Two and Sixteen Years. Viral Hepat J. 2017;23:46-49.

Address for Correspondence: Nurcan Kolancalı MD, University of Health Sciences, Haydarpaşa Numune Training and Research Hospital, Clinic of Pediatrics, Istanbul, Turkey Phone:+90 5438235725 E-mail: drnurcan86@gmail.com ORCID ID: orcid.org/0000-0002-1137-0440 Received: 15.02.2017 Accepted: 06.11 .2017

${ }^{\circ}$ Copyright 2017 by Viral Hepatitis Society / Viral Hepatitis Journal published by Galenos Publishing House. 


\section{Introduction}

Hepatitis A virus (HAV) appears at earlier ages in developing countries depending on socio-economic and hygienic conditions. When hepatitis A infection occurs in early childhood, it progresses in an asymptomatic manner. The symptoms and complications increase with age $(1,2)$. The age in which individuals face HAV and the frequency of HAV infection are directly related with the socioeconomic conditions of the country and the region $(3,4,5)$. Low socioeconomic level, living in crowded areas, being in rural areas and low educational status of parents increase the HAV prevalence $(6,7)$.

$\mathrm{HAV}$, which is highly infectious, is a member of the picornaviridae family. Infection is spread via the fecal-oral route as well as through ingestion of contaminated food and water (3). In diagnosing the acute disease, anti-HAV IgM positivity in serum is adequate. AntiHAV IgM indicates an ongoing or a past infection. Anti-HAV lgG starts to be positive a few weeks after the infection persists for years after infection and confer life-long immunity (8).

Hepatitis A can be prevented through, passive hepatitis $A$ immunization. The vaccine is administered twice in the 0,6 th or $12^{\text {th }}$ months of life (9). HAV vaccination was added to the routine schedules by the Ministry of Health of Turkey in 2012.

\section{Materials and Methods}

The study group consisted of 400 children aged 2-16 years who were admitted to the pediatric outpatient clinic in Health Sciences University, Haydarpaşa Training and Research Hospital. The study started after obtaining consent from parents of the children. Special care was given to select children who did not have any chronic diseases. The study was approved by the Local Ethics Committee of Health Sciences University, Haydarpaşa Numune Training and Research Hospital (approval no: HNEAHKAEK 2016/67), and was conducted between July 2016 and September 2016.

Data on name, family name, age, gender and telephone number was recorded, and the parents were asked whether or not their children had been vaccinated against hepatitis $A$.

Blood samples of the children were centrifuged at the medical microbiology laboratory. The hepatitis A serologic markers (antiHAV Ig M, anti-HAV lgG) were determined using enzyme-linked immunosorbent assay and the measurements were made in mIU/ $\mathrm{mL}$ (Architect Systems and Abbott Diagnostics Division, the USA). The results were evaluated in the light of the recommendations of the manufacturer company.

\section{Statistical Analysis}

To evaluate the findings obtained in the study, the NCSS 2007 (Kaysville, Utah, USA) program was used for statistical analyses. Definitive statistical methods were used to evaluate the study data (average values, standard deviation, median, frequency, rates, minimum, maximum values, etc.). Pearson's chi-square test, Fisher's exact test and Yates's correction for continuity were used in comparing the qualitative data. The results were evaluated at a $95 \%$ confidence interval and a $p$ value of less than 0.05 was considered statistically significant.

\section{Results}

Our study was conducted on 400 cases [55.8\% of whom were males $(n=223)$, and $44.3 \%(n=177)$ were females]. The age of the patients varied between 2 and 16, and the mean age was $10.08 \pm 4.18$ years. In this study $19.5 \%(n=78)$ of the children were aged between 2 and 5 years, which is the preschool period, and $80.5 \%(n=322)$ of them were aged between 6 and 16 years, which is schooling period (Table 1).

Overall, 98.3\% ( $n=393$ ) of children were anti-HAV IgM-negative and $1.8 \%(n=7)$ were positive. $72.8 \%(n=291)$ were anti-HAV lgG-negative and $27.3 \%(n=109)$ were positive. $89 \%(n=356)$ of children were unvaccinated and $11 \%$ had been vaccinated against hepatitis $A$ (Table 2).

$41 \%(n=32)$ of the preschool children were negative for antiHAV IgG and $59 \%(n=46)$ were positive. $80.4 \%$ of the children who were at schooling period $(n=259)$ were negative and $19.6 \%(n=63)$ were positive (Table 3).

$43.6 \%$ of the preschool children $(n=34)$ were unvaccinated while $56.4 \%(n=44)$ had been vaccinated. All the school age children ( $n=322)$ were unvaccinated (Table 4).

All preschool children who were vaccinated $(n=44)$ and $5.9 \%$ of children who were unvaccinated $(n=2)$ were anti-HAV IgG-positive

\begin{tabular}{|l|l|l|}
\hline \multicolumn{3}{|l|}{ Table 1. The distribution of the definitive characteristics } \\
\hline Gender; $\mathrm{n}(\%)$ & Female & $177(44.3)$ \\
\cline { 2 - 3 } & Male & $223(55.8)$ \\
\hline \multirow{2}{*}{ Age (years) } & min-max (median) & $2-16(11)$ \\
\cline { 2 - 3 } & Ave \pm SD & $10.08 \pm 4.18$ \\
\hline Age groups; $\mathrm{n}(\%)$ & Pre-school (age 2-5) & $78(19.5)$ \\
\cline { 2 - 3 } & School period (age 6-16) & $322(80.5)$ \\
\hline \multirow{2}{*}{$\begin{array}{l}\text { Type of the patient; } \mathrm{n} \\
\text { (\%) }\end{array}$} & Outpatient & $395(98.8)$ \\
\cline { 2 - 3 } & Hospitalized & $5(1.3)$ \\
\hline SD: Standard deviation, min: Minimum, max: Maximum \\
\hline
\end{tabular}

Table 2. The distribution of the anti-Hepatitis $\mathrm{A}$ virus $\lg \mathrm{M}$, anti-Hepatitis $A$ virus $\lg G$ and vaccination results

\begin{tabular}{|l|l|l|}
\hline Anti-HAV IgM; n (\%) & Negative & $393(98.3)$ \\
\cline { 2 - 3 } & Positive & $7(1.8)$ \\
\hline \multirow{2}{*}{ Anti-HAV IgG; $\mathrm{n}(\%)$} & Negative & $291(72.8)$ \\
\cline { 2 - 3 } & Positive & $109(27.3)$ \\
\hline Vaccination; n (\%) & Negative & $356(89)$ \\
\cline { 2 - 3 } & Positive & $44(11)$ \\
\hline HAV: Hepatitis A virus, IgM: Immunoglobulin M, IgG: Immunoglobulin G \\
\hline
\end{tabular}

Table 3. Evaluation of anti-Hepatitis A virus IgG results according to the groups

\begin{tabular}{|l|l|l|l|l|}
\hline \multicolumn{2}{|c|}{} & $\begin{array}{l}\text { Preschool } \\
\text { (2-5 years) } \\
\text { (n=78) }\end{array}$ & $\begin{array}{l}\text { School period } \\
\text { (6-16 years) } \\
\text { (n=322) }\end{array}$ & \\
\cline { 2 - 4 } & $\mathbf{n}(\%)$ & n (\%) & p \\
\hline \multirow{2}{*}{ Anti-HAV IgG } & Negative & $32(41)$ & $259(80.4)$ & \multirow{2}{*}{ a,001** } \\
\cline { 2 - 4 } & Positive & $46(59)$ & $63(19.6)$ & \\
\hline \multicolumn{2}{|l|}{ aPearson chi-square test, ${ }^{* *}$ p $<0.01$, HAV: Hepatitis A virus, IgG: Immunoglobulin G } \\
\hline
\end{tabular}


and $94.1 \%(n=32)$ were negative. The school age children $(n=322)$ had not been vaccinated; $19.6 \%(n=63)$ of them were anti-HAV lgG-positive and $80.4 \%(n=259)$ were negative.

\section{Discussion}

The age to face HAV infection and the prevalence of hepatitis A vary among different parts of the World due to different socio-economic conditions $(10,11)$. The seroprevalence studies conducted at various parts of our country have shown that there were differences between regions based on the socio-economic conditions, and there were differences even between some areas within the same region or between the urban and rural areas.

Erdoğan et al. (6) conducted a study with 0-19 age group children in the city of Edirne and determined that the anti-HAV positivity in 2-5 age group, 6-10 age group 11-14 age group and $15-19$ age group was $4.4 \%, 25 \%, 37.3 \%$, and $43.2 \%$, respectively. Yapicioglu et al. (12) conducted a study on children aged 2-6 years in Adana, and determined a HAV IgG positivity of $28.8 \%$. In their study performed on 1-6 age group children in the Konya region, Atabek et al. (13) found that the anti-HAV IgG positivity rate in the urban and rural areas was $25.7 \% 67.8 \%$, respectively. Karaman et al. (14) reported an anti-HAV IgG positivity rate of $54.9 \%$ among 1-15 age group children in the Van region.

As a result of socio-economic development, access to clean water sources, application of hygiene principles and with the help of the hepatitis A vaccination practices, which started as of late 2012, the number of the cases decreased from 3624 in 2012 to 707 in 2015; and the prevalence decreased from 4.8 per in 100.000 2012 to 0.9 per 100.000 in 2015 (15).

In this study, which was conducted with 400 children aged 2-16 years, who were admitted to our hospital, the anti-HAV IgG seropositivity was determined as $27.3 \%$. While $41 \%$ of the preschool children were negative for anti-HAV IgG, 59\% were positive. It was found that $80.4 \%$ of school age children were anti-HAV IgG-negative and $19.6 \%$ were positive. We associate these results with hepatitis $A$ vaccination included in the routine schedules by the Ministry of Health of Turkey in 2012 and administered in preschool children aged 18 and 24 months given in 2 doses.

The hepatitis $A$ vaccination rate was determined as $11 \%$ in our study. We believe that the low rate of vaccination found in this study was associated with the fact that hepatitis A vaccination that was included in the routine schedules in 2012 and $19.5 \%$ of the 400 children included in our study were aged 2-5 years; the vaccination status was declared by the mothers, who might have forgotten, and with the vaccination status cards which might be ignored to be filled out in some situations (Table 4).

\begin{tabular}{|c|c|c|c|c|}
\hline & & $\begin{array}{l}\text { Preschool } \\
\text { (age 2-5) } \\
(n=78)\end{array}$ & $\begin{array}{l}\text { School period } \\
\text { (age 6-16) } \\
(n=322)\end{array}$ & \multirow[b]{2}{*}{$\mathbf{p}$} \\
\hline & & n (\%) & n (\%) & \\
\hline \multirow{2}{*}{ Vaccination } & Negative & $34(43.6)$ & $322(100)$ & \multirow[t]{2}{*}{$\mathrm{a} 0.001 * *$} \\
\hline & Positive & $44(56.4)$ & $0(0)$ & \\
\hline \multicolumn{5}{|c|}{ aPearson chi-square test, ${ }^{* *} \mathrm{p}<0.01$} \\
\hline
\end{tabular}

Immunity against HAV being acquired with vaccination or by having the infection itself, which are not serologic markers in distinction, and considering only anti-HAV lgG positivity in determining hepatitis $\mathrm{A}$ immunity are among the limitations of our study.

Especially, when the seropositivity rate found in our study is compared with that in the eastern and southeastern regions of Turkey, this rate is clearly low $(7,14)$. We consider that this may stem from the fact that the socio-economic conditions, infrastructure, conscious levels of families and the application of hygiene conditions being better in Istanbul when compared with that in the eastern and southeastern regions.

According to the results of the present study, the seropositivity rate in Istanbul was found to be lower than reported in the previous years (16). We may associate this situation with the fact that the socio-economic level in the whole country is increasing, hygiene conditions are improving, bottled water is used, and the educational level within families is increasing.

\section{Conclusion}

In the present study, although the hepatitis A prevalence was found to be lower when compared with the eastern and southeastern regions of Turkey, it is still higher than that in developed countries. For prevention of hepatitis $A$, the socioeconomic conditions of the country must be improved, better sanitary conditions must be provided, and the awareness of the infection must be raised. For the purpose of acquiring immunity against the disease without being infected with it, hepatitis A vaccination, which is included in the National Vaccination Program of the Ministry of Health, must be applied in an efficient manner.

\section{Ethics}

Ethics Committee Approval: The study was approved by Local Ethics Committee of Health Sciences University, Haydarpaşa Numune Training and Research Hospital (approval no: HNEAHKAEK 2016/67)

Informed Consent: Informed consent was taken from the parents.

Peer-review: Externally and internally peer-reviewed.

\section{Authoring Contributions}

Surgical and Medical Practices: N.K., Concept: N.K., Z.E.Ö., S.A., C..N., Design: N.K., Ç.N., Data Collection and Data Processing: N.K., Analysis and Interpretation: N.K., S.A., Literature Search: N.K., Z.E.Ö., Writing: N.K.

Conflict of Interest: No conflict of interest was declared by the authors.

Financial Disclosure: The authors declared that this study received no financial support.

\section{References}

1. Tosun S, Ayaz H, Deveci S, Aksu S. Cocuk ve erişkinlerde hepatit A virusu ile karşılaşma durumunun değerlendirilmesi. Antalya: X.Ulusal Viral Hepatit Kongre Kitabı; 2010; p. 121.

2. Jacobsen $\mathrm{KH}$, Wiersma ST. Hepatitis A virus seroprevalence by age and world region, 1990 and 2005. Vaccine. 2010;28:66536657. 
3. NadaYazigiand William F. Balistreri: Viralhepatitis. In: Kleigman RM, Behrman RE, Jenson HB, Stanson BF, (eds.), Nelson textbook of Pediatrics 20th Edition; 2015; p. 1680-1690.

4. Badur S. Viral Hepatitler (HAV, HBV, HDV). Içinde: Ustaçelebi Ș, Abacıoğlu H, Badur S, (eds.), Moleküler, Klinik, Tanısal Viroloji. Ankara: Güneş Kitabevi; 2004; p.175-183.

5. Jacobsen $\mathrm{KH}$, Koopman JS. Declining hepatitis A seroprevalence a global review and analysis. Epidemiol Infect. 2004;132:10051022.

6. Erdoğan MS, Oktun $M$, Tatman-Otkun $M$, Akata $F$, Türe $M$. The epidemiology of hepatitis a virus infection in children, in Edirne, Turkey. Eur J Epidemiol. 2004;19:267-273.

7. Taşyaran MA, Akdağ R, Akyüz M, Parlak M, Ceviz N, Yılmaz S. Erzurum bölgesi çocuklarında fekal oral bulaşan hepatit viruslarının seroprevalansı. Klinik Dergi. 1994;7:74-75.

8. Shah U, Habib Z, Kleinman RE. Liver failure attributable to hepatitis A virus infection in a developing country. Pediatrics. 2000;105:436438.

9. Malay S, Tizer K, Lutwick LI. Current Update of Pediatric Hepatitis Vaccine Use. Pediatr Clin North Am. 2000;47:395-406.

10. Mostafavi N, Kelishadi R, Kazemi E, Ataei B, Yaran M, Motlagh ME, Qorbani M, Heshmat R, Tajadini MH, Ghaffari Hoseini S.
Comparison of the prevalence and risk factors of hepatitis $A$ in 10 to 18-year-old adolescents of sixteen IranianProvinces: The CASPIAN-III Study. Hepat Mon. 2016;16:e36437.

11. Stephen MF, lan DG. Hepatitis A Virus. In: Mandell GL, Bennett JE, Dolin R, (eds.), Principles and Practice of Infectious Disease. Churchill Livingstones: Newyork: 2000;p. 1920-1940.

12. Yapicioglu $H$, Alhan $E$, Yildizdas $D$, Yaman A, Bozdemir $N$. Prevalence of hepatitis $A$ in children and adolescents in Adana, Turkey. Indian Pediatr. 2002;39:936-941.

13. Atabek ME, Findık D, Gulyuz A, Erkul I. Prevalence of anti-HAV and anti- HEV antibodies in Konya, Turkey. Health Policy. 2004;67:265269.

14. Karaman S, Karaman K, Kızılyıldız BS, Ceylan N, Kaba S, Parlak M, Beger B, Ceylan A. Seroprevalance of hepatitis a and associated factors among 1-15 year old children in Eastern Turkey. Int J Clin Exp. 2015;8:19394-19399.

15. http://www.medikalakademi.com.tr/hepatit-a-asisi-sayesindeturkiyede-hastalıkgorulme-sikligi-5-kat-azaldi.Hepatit A AşıSı Sayesinde Türkiye'de Hastalık Görülme Sıklığı 5 Kat Azaldı. Medikal Akademi; 2016.

16. Aldeniz C, Çavuşoglu S, Altunay H. Istanbul'da A ve E hepatitlerinin seroprevalansı. Viral Hepat J. 1998:31-36. 